\section{K.C. Taylor Assumes Duties as 1987 MRS President}

Kathleen C. Taylor assumed the post of MRS President on January 1, 1987 and will lead the Society for the 1987 calendar year. Taylor has been active in MRS since the mid-1970s, serving as meeting chair for the 1979 MRS Annual Meeting and as symposium organizer for that year's symposium on Catalyst Preparation and Maintenance of Catalyst Activity. Taylor was instrumental in maintaining the sound financial operation of the Society during a period of very rapid evolution and growth. She served as Treasurer for five years (1980-1984), Councillor for five years (1978-1979 and 1983-1985), 1985 Second Vice President, and 1986 First Vice President. She also established the MRS Graduate Student Award Program in 1980 and served on the Select Committee for Establishment of MRS Headquarters.

In addition to her MRS activities, she has held numerous positions with the American Chemical Society and the Michigan Catalysis Society. She is a member of the Air Pollution Control Association and the Society of Automotive Engineers and serves on the advisory board of Environmental Science and Technology. Taylor is a member of various committees, including the National Research Council's Committee on Toxicology of the Commission on Life Sciences, the National Science Foundation's Materials Research Advisory Committee, the U.S. National Committee for the International Union of Pure and Applied Chemistry, and Panel 5 on Education of the national Materials Science and Engineering Study. She is the author of numerous scientific papers and is a frequently invited speaker/chair of professional scientific symposia/workshops.

Taylor, who holds a PhD in physical chemistry from Northwestern University, joined General Motors Research Laboratories in 1970, where she is currently head of the Physical Chemistry Department. She has also been head of the Environmental Science Department, and group leader and senior research chemist in the Physical Chemistry Department.

Taylor sees 1987 as a challenging year for the Society, a year in which important decisions must be weighed to maintain a careful balance of demands on resources to ensure cost-effective activities and services to the membership. Journal of Materials Research, rapidly growing local sections and student chapter activities, as well as cooperative efforts with international professional materials groups will provide a myriad of opportunities for the membership this year.

"Kathy's past contributions have been monumental and have greatly influenced the Society as we know it today," emphasized 1986 MRS President Gordon E. Pike.
"Her strong sense of the goals and needs of the membership will make her tenure as President a progressive one," he added. "The Executive Committee looks forward to working with her during a year which is sure to be another important period of advancement and service to the materials profession."

\section{AIP Corporate Associates Meet at Exxon}

On October 21 and 22, 1986 the Corporate Associates of the American Institute of Physics (AIP) gathered for their 28th Annual Meeting at Exxon Research and Engineering Corporation's Corporate Research Lab in Annandale, New Jersey. The meeting consisted of two technical sessions, a session on Matters of Policy, and tours in 12 separate research areas within the Exxon research facility. Prior to the tours, David Moncton highlighted Exxon's in volvement in the use of synchrotron radiation and neutron scattering at major national facilities, and Brian Flannery highlighted Exxon's development of a new three-dimensional $x$-ray microtomography technique.

The first session, a technical session dealing with the physics of complex materials, included presentations by James Langer (University of California at Santa Barbara) on "Pattern Formation in Crystal Growth," Pierre DeGennes (College de France) on "Interface Dynamics and Wetting," David Wilkinson (SchlumbergerDoll Research) on "Multiphase Flow in Porous Media," S. Bhattacharya (Exxon) on "Dynamics of Ordered Fluids, and Charles Slicter (University of Illinois) on the "Probing of Metal Catalysts with NMR."

The second technical session comprised talks by Robert Laughlin (Lawrence Livermore National Laboratory) on the "Fractional Quantum Hall Effect," James Smith (Los Alamos National Laboratory) on "Heavy Electrons," Albert Hibbs (Jet Propulsion Laboratory) on the "Voyager II Probe of Uranus," and Walter Broecker

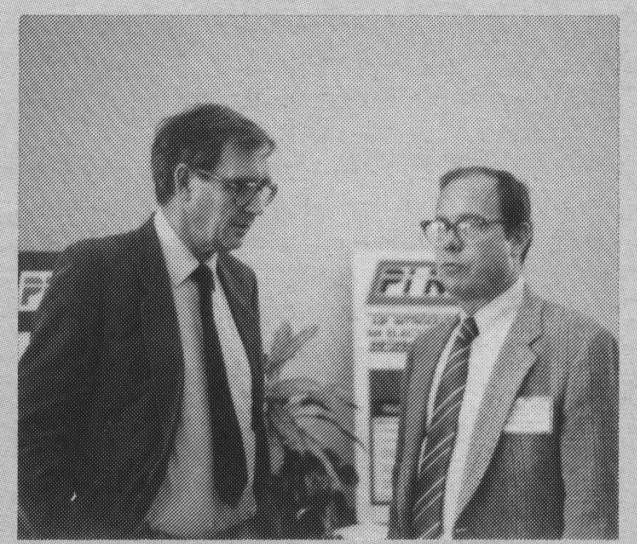

1986 MRS President G. Pike (right) with the new AIP Governing Board chairman, H. Frauenfelder.
(Columbia University) on the "Carbon Dioxide Greenhouse Effect."

In the session on Matters of Policy, four speakers discussed factors affecting scientific research and education. D. Alan Bromley (Yale University) discussed the "State of University Research"; Alan McClelland (E.I. duPont de Nemours \& Company) spoke on "Science Education: Lessons from Music and Latin"; Donald Braben (B.P. International, Ltd.) discussed "Basic Research and Innovation"; and Shirley Malcolm (American Association for the Advancement of Science) spoke on the "Implication of the Elimination of the Undergraduate Education Degree in the Education of Science Teachers."

Additional comments on the best implementation of research in industry were included in introductory welcoming remarks by David R. Clair, president of Exxon Research and Engineering Company. The banquet on the first evening was followed by a presentation by Michael Barnsley (Georgia Institute of Technology) on "Fractal Image Encoding." And, before the final session of the event, the AIP Science Writing Award in Physics and Astronomy was presented to Donald Goldsmith (Pillsbury, Madison and Sutro) for his book Nemesis: The Death Star.

Since much of the content of the technical presentations can be found in the technical literature, it will not be repeated here. Some points concerning policy matters, however, are reviewed below. David Clair noted that "innovation is a long and formidable chain with many opportunities for weak links to develop." He pointed out that "technology becomes a cost reduction tool rather than an instrument for revitalization and renewal in maturing industries." Continuing, he reminded the audience that "an economic slowdown usually results in cutbacks to research and technology and to prevent this, technology needs to be a respected member of the business team before a crisis occurs." He noted the tendency in mature industries to neglect basic research and development (Exxon and Shell were acknowledged as exceptions). He described applied laboratories in industries such as the petroleum industry as "customers of the basic research labs," saying that "strong suction on the output of basic research should be provided by the applied laboratories." In addition, he noted that "ways to measure progress in basic research and communicate it in a form understandable to funders is necessary." At the conclusion of his highlights on the utilization of synchrotron and neutron facilities by Exxon, Moncton pointed out, in a manner consistent with Clair's remarks, that "we are very sensitive to the need to have this big investment pay off over the next few years."

Bromley's address dealt with the topics covered by the White House Science Coun- 
cil's study of university research. Several comments were critical of the current situation on university campuses. For example, Bromley indicated that "university/industry partnerships are more talk than reality and usually depend on the presence of a particular individual rather than on an institutional philosophy." $\mathrm{He}$ also indicated that the department structures at most universities are a "loose coalition of feudal fiefdoms" and mitigate against implementing interdisciplinary research programs. Bromley contended that the U.S. is generally in front technically but clearly trailing in focus areas, such as optics in France and ultrapure materials in the USSR. His panel recommended a ten-year, ten-billion-dollar program to fund facilities "catch-up" on university campuses, funded with new money and not simply a tax on existing research dollars. Half of the funds would come from sources other than the federal government.

McClelland drew several analogies to highlight the contention that the classical disciplines on university campuses are anachronistic. Mentioning the last century's Latin and Greek core curricula which dominated for 100 years, he pointed to university chemistry and physics departments, indicating that by the next century, they may have gone the way of Latin and Greek. His evidence for this contention rests on student matriculation trends in chemistry and physics programs compared with those in engineering and the biological sciences. Describing the rejection by older departments on university campuses of the newer branches of their own disciplines, he illustrated "scholarly suicide," such as the English departments' rejection of journalism, the mathematics departments' rejection of statistics and of computer and information sciences, and the chemistry departments' rejection of chemical process engineering. All these trends mitigate in favor of the disappearance of the older core science curricula. He pointed out that $85 \%$ of the research at duPont, his home institution, is in polymers and is not represented in the chemistry departments of major, high-prestige universities. One solution he offered is the introduction of dynamic research areas at the high school level to induce new college students to demand instruction in the more exciting forefront areas.

Braben compared the differences in the criteria used by the Venture Research Unit (B.P. International, Ltd.) in selecting projects and principal investigators for funding with those used by the normal national funding organizations. In each instance, the national funding organizations emphasized disciplinary or problemoriented categories, invoking criteria which would produce caution and reduce serendipity in their funded research. The Venture Research Unit approach rests on identifying the appropriate investigators and essentially giving them their heads.

Malcolm decried the situation in the education of science teachers, pointing to the effect of eliminating the undergraduate education degree, particularly for science educators. Her conclusion, a significant one, was that the buck will now stop with the science departments rather than the education departments at the undergraduate level since it will be their responsibility to supply to the graduate schools students who are very well founded in their respective disciplines; i.e., "they can no longer blame the education departments for the poor quality of science education in the schools."

The 1986 meeting of the AIP Corporate Associates was attended by several MRS officers: Gordon Pike, 1986 MRS President; Clifton Draper, 1986 Treasurer; John Baglin, 1986 Second Vice President; and Elton Kaufmann, 1986 Immediate Past President. Before the meeting, Pike had an opportunity to discuss with the AIP Governing Board and its new chairman, Prof. Hans Frauenfelder, issues of mutual concern to AIP and MRS.

\section{MRS BULLETIN Expands to Eight Issues in 1987}

Elton N. Kaufmann, chairman of the MRS BULLETIN Editorial Board, has announced that the MRS BULLETIN will publish a total of eight issues in 1987 to accommodate the recent rapid growth in technical articles and news. The BULLETIN, which begins its twelfth year of publication and was previously published every other month, has expanded its coverage of news and scientific developments in 1986 in parallel to the Society's farreaching interests and activities.

"The BULLETIN is receiving wide attention in the United States and internationally, from both the scientific community and government leaders. It is becoming an important source of information on trends and developments in materials research and education, and serves as a voice for the materials profession on issues such as national and international priorities and policies," Kaufmann said. "The BULLETIN will continue to grow as a forum for the exchange of ideas and opinion from the diverse international scientific community."

During 1987, special issues will focus on recent developments in ion beams, glasses, materials characterization, ceramics, education, and polymers. Other regular features will also continue to expand: editorials, news, new products, the "Up Close" series on materials laboratories, government issues, book reviews, and more. Many solicited and contributed articles are now under preparation for up- coming issues, and new ideas and topics are always welcome.

If you would like to contribute to the MRS BULLETIN or offer suggestions on areas you would like to see covered, contact Elton N. Kaufmann, Lawrence Livermore National Laboratory, P.O. Box 808, L-217, Livermore, CA 94550, telephone (415) 423-2640; or Gail Oare, Materials Research Society, 9800 McKnight Road, Suite 327, Pittsburgh, PA 15237, telephone (412) 367-3036.

\section{Von Hippel Award Nominations Sought}

\section{The Society's \\ Most Prestigious Honor}

The MRS Awards Committee, chaired by Past President Gordon Pike, has announced that nominations are being accepted for the Society's highest award, the Von Hippel Award of the Materials Research Society. The Award is an international hallmark of excellence in the field of materials research, numbering nine prominent materials scientists as past recipients.

The Award is named for the Emeritus Professor of the Massachusetts Institute of Technology, Arthur von Hippel, whose laboratory pioneered the collaborative, interdisciplinary research that subsequently has taken the identity of "materials science." It recognizes those qualities most prized by materials scientists - brilliance and originality of intellect, combined with vision that transcends conventional scientific disciplines. The Award is presented annually by the Society at its Fall Meeting.

Past recipients of the Award are:

Prof. Arthur von Hippel

Dr. William O. Baker

Prof. David Turnbull

Prof. W. Conyers Herring

Prof. James W. Mayer

Prof. Clarence M. Zener

Prof. Sir Peter B. Hirsch

Dr. Walter L. Brown

Dr. John W. Cahn

Prof. Minko Balkanski

The recipient is selected by majority vote of the MRS Council from a slate of candidates that is prepared by the Awards Committee. Nominations should be made to the MRS Awards Committee. Names put into nomination are, in accordance with MRS Bylaws, considered active for three years. Nominations must be made using the Von Hippel Award Nomination Form and should be accompanied by supporting documentation.

Nominations should be sent to: Gordon E. Pike, Sandia National Laboratories, Division 1815, Albuquerque, NM 87185. 